\title{
Abdominal radiography in woman with unrecognised pregnancy
}

\author{
Maria Chiara De Nardo (D) ,' Chiara Maninchedda, ${ }^{2}$ Eleonora Romeo, ${ }^{1}$ \\ Fabio Natale (D) ${ }^{1}$
}

'Department of Maternal and Child Health, Sapienza University of Rome, Roma, Lazio, Italy

${ }^{2}$ Neonatal Unit, Chelsea and Westminster Hospital NHS Foundation Trust, London, UK

\section{Correspondence to}

Chiara Maninchedda; marybrown88@libero.it

Accepted 23 September 2020

\section{DESCRIPTION}

A 23-year-old woman presented to the emergency department for severe abdominal pain and vomiting over the last 12 hours. She reported that she was on the second day of her menstrual period and was taking oral contraceptives. The patient was suffering and upset. Vital signs were stable; no fever. On physical examination, abdomen was distended, tender, bowel sounds and function were normal and Blumberg's sign was positive. The rest of the examination was unremarkable. A blood test was performed and showed neutrophilic leucocytosis (white blood cells $1461 \times 10^{9} / \mathrm{L}, \mathrm{N}$ $1263 \times 10^{9} / \mathrm{L}$ ) and a slight increase in $\mathrm{C}$ reactive protein $(0.87 \mathrm{mg} / \mathrm{dL})$. Pregnancy test was sent. She was started on non-steroidal anti-inflammatory drug and proton pump inhibitor. Gynaecological referral was requested but, in the meanwhile, an abdominal X-ray showed the presence of a fetus in the abdomen (figure 1). An abdominal ultrasound confirmed the presence of a vital fetus. The unaware father was called by the medical staff in order to be informed about the paternity. On gynaecological examination, full cervical dilatation was noted, so the woman was urgently admitted to labour ward where the baby was spontaneously delivered 10 hours later at 38 weeks clinical gestational age.

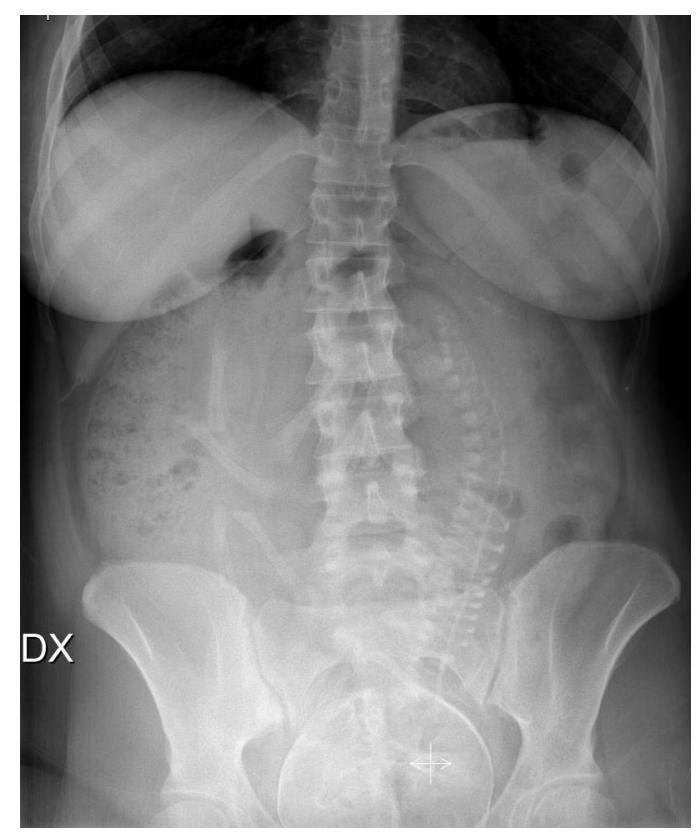

Figure 1 Abdominal X-ray showing the presence of a fetus in the abdomen. Normal bowel gas pattern. Faeces in ascending colon.
The baby had a normal transition to extrauterine life with an Apgar score of 8 at $1 \mathrm{~min}$ and 9 at 5 min, and a weight of $3180 \mathrm{~g}$. Imaging studies are crucial in the diagnostic evaluation of significant medical conditions. The use of X-ray has become so common in medicine that it may be performed inadvertently before the diagnosis of pregnancy. Fetal exposure to ionising radiation is associated with a higher risk of anomalies, growth restriction or abortion for the fetus. The fetal risk is higher if radiation exposure occurs during the first trimester of gestation and at extremely high dose. However, according to The American College of Obstetricians and Gynecologists (ACOG) Committee, with a few exceptions, the dose of radiation exposure through radiography is much lower than the dose associated with teratogenesis. Although ultrasonography and MRI are the imaging techniques of choice for the pregnant patients, the ACOG Committee states that, if necessary or more readily available, X-ray should be performed. ${ }^{1}$

\section{Learning points}

- With a few exceptions, the dose of radiation exposure through radiography is much lower than the dose associated with teratogenesis.

- The risk to a fetus from ionising radiation is higher if radiation exposure occurs during early embryogenesis and at extremely high dose.

- If necessary or more readily available for diagnosis, radiography should not be withheld from a pregnant patient.

Contributors MCDN: drafting, creation and revision of case report. CM: acquisition of information, drafting and interpretation. ER: acquisition of information, drafting and review. FN: overview and critical revision for important intellectual content.

Funding The authors have not declared a specific grant for this research from any funding agency in the public, commercial or not-for-profit sectors.

Competing interests None declared.

Patient consent for publication Obtained.

Provenance and peer review Not commissioned; externally peer-reviewed.

\section{ORCID iDs}

Maria Chiara De Nardo http://orcid.org/0000-0001-9878-9094

Fabio Natale http://orcid.org/0000-0002-2513-9899

\section{REFERENCE}

1 No CO. Committee opinion no. 723 summary: guidelines for diagnostic imaging during pregnancy and lactation. Obstet Gynecol 2017;130:933-4. 
Copyright 2020 BMJ Publishing Group. All rights reserved. For permission to reuse any of this content visit https://www.bmj.com/company/products-services/rights-and-licensing/permissions/

BMJ Case Report Fellows may re-use this article for personal use and teaching without any further permission.

Become a Fellow of BMJ Case Reports today and you can:

- Submit as many cases as you like

- Enjoy fast sympathetic peer review and rapid publication of accepted articles

Access all the published articles

Re-use any of the published material for personal use and teaching without further permission

Customer Service

If you have any further queries about your subscription, please contact our customer services team on +44 (0) 2071111105 or via email at support@bmj.com.

Visit casereports.bmj.com for more articles like this and to become a Fellow 